White, Professional, or Female Immigrants Only, Please: U.S. American's Desired Social Distance from Immigrants

\author{
Amanda N. Faherty ${ }^{1}$ and Brien K. Ashdown ${ }^{2}$ \\ Clark University ${ }^{1}$, Hobart \& William Smith Colleges ${ }^{1}$
}

\begin{abstract}
Authors Note
The authors would like to thank Mengqi Liu for her help on this manuscript. Findings from this manuscript were presented at the 2017 annual conference for the Society for Cross-Cultural Research in New Orleans, LA. Correspondence (in English or Spanish) regarding this article can be sent to Brien K. Ashdown, Department of Psychology, Hobart \& William Smith Colleges, Geneva, NY 14456; ashdown@hws.edu
\end{abstract}




\begin{abstract}
The United States of America has a long history of discriminatory immigration and refugee policies that have resulted in disparities of health, education, employment and wages for many. This official discrimination is reflected in the personal prejudice of many U.S. Americans. In this study, we compare the social distance that participants desire from immigrants by randomly assigning participants $(N=616)$ a fictional vignette that alters the nation of origin (England, India, Syria), gender (man, woman) and occupation (doctor, teacher, janitor) of an immigrant. Participants demonstrated a preference for professional immigrants, women immigrants, and immigrants from England while controlling for age, though there were no significant interaction effects. These findings imply that U.S. American's attitudes about immigrants and immigration are not objective. We believe that these prejudicial attitudes are reflected in policy and law, suggesting a need to construct processes to protect such policies from subjective and prejudicial attitudes.
\end{abstract}

Keywords: immigration attitudes; refugees; gender; identity; immigrants

\title{
Resumen
}

Los Estados Unidos de América tiene una larga historia de políticas discriminatorias sobre la inmigración y los refugiados, lo que ha dado lugar a disparidades de salud, educación, empleo y salarios para muchos inmigrantes y refugiados. Esta discriminación oficial se refleja en el prejuicio personal de muchos estadounidenses. En este estudio, comparamos la distancia social que los participantes desean de los inmigrantes. Asignamos aleatoriamente una viñeta ficticia a 
los participantes $(\mathrm{N}=616)$. Las viñetas alteran en la nación de origen (Inglaterra, India, Siria), género (hombre, mujer) y ocupación (doctor, maestro, custodio) de los inmigrantes. Los participantes demostraron una preferencia para los inmigrantes quienes sean profesionales, mujeres y de Inglaterra mientras que controlábamos por edad, aunque no hubo efectos significativos de interacción. Estos datos implican que las actitudes de los estadounidenses sobre los inmigrantes y la inmigración no son objetivos. Creemos que estas actitudes prejuiciosas se reflejan en las políticas y leyes, lo que sugiere la necesidad de construir procesos para proteger tales políticas de actitudes subjetivas y perjudiciales.

Palabras claves: actitudes de inmigración; refugiados; género; identidad; inmigrantes 


\section{White, Professional, or Female Immigrants Only, Please: U.S. American's Desired Social Distance from Immigrants}

Issues related to voluntary (i.e., not slavery-based) immigration and refugee situations have been important to U.S. Americans since at least the Naturalization Act of 1790, if not before. Since then, many changes to U.S. immigration law and asylum regulations have occurred (for a complete discussion, see Daniels, 2002). The issue took on new life during the 2016 U.S. presidential election between Donald Trump and Hillary Clinton. Trump, for example, advocated (and still advocates) both building a wall along the southern U.S. border (Time, 2015) and blocking people of Muslim belief from entering the country (BBC, 2017). Much of this campaign rhetoric was occurring at the time the world was facing a massive refugee crisis, mostly due to the conflict in Syria (Connor, 2017). Campaign speeches are often heated and emotional, and so are people's responses to them - and the reactions to Trump's speeches on these topics were not an exception. Because we believe that the field of psychology has much to offer when it comes to immigration and immigration policy (Berry, 2001), we wanted to determine if the campaign rhetoric of 2016 matched people's more implicit attitudes toward immigration and immigrants. We did this by asking participants to complete a measure of social distance after reading a vignette about a (fictional) immigrant.

\section{History of Immigration in the United States}

The U.S. has a long history of discriminatory immigration law and policy (Daniels, 2002). The Naturalization Act of 1790 , mentioned previously, only allowed free White men to become citizens of the United States, excluding women, free Blacks, American Indians, and other non-White residents. The Chinese Exclusion Act of 1882 prohibited most people of Chinese heritage from entering the United States, and laws passed that same year banned 
individuals with certain intellectual disabilities and mental illnesses from immigrating to the U.S.

Later, immigration acts in 1921 and 1924 set quotas, or limits, for the number of immigrants admitted from each foreign country, and these quotas were often created to discriminate against certain nationalities (Immigration and Naturalization Service [INS], 2012).

After the Second World War, immigration policies were created that allowed refugees, especially from the war in Europe, to more easily immigrate to the United States. It was not until 1965, however, that all racial and national quotas (or limits) were removed from U.S.

immigration law. Finally, in 1980, the U.S. developed its first general policy regarding refugee migration, rather than depending on specific laws passed for specific refugee crises as had occurred prior to 1980 (INS, 2012). Since the middle of the twentieth century, the majority of immigrants to the United States have come from Asia and South America instead of Europe, which was traditionally the greatest provider of immigrants to the U.S. (INS, 2012).

\section{Attitudes about Immigration in the United States}

While U.S. immigration and refugee policy has changed over the years, perhaps one of the only constants has been the attitudes U.S. citizens have had toward immigrants and refugees. Throughout the history of immigration in the United States, different immigrant groups have had a turn, so to speak, at being oppressed and discriminated against. For example, during the nineteenth and early twentieth centuries, more than 5 million Irish people immigrated to the United States (Miller, 1985) and many of them faced discrimination in employment, wages, and housing - and this discrimination was greater than that experienced by immigrants from other countries, such as England and Wales (Blau, 1980). This discrimination was also expressed in people's personal attitudes, with intermarriage between immigrants and non-immigrants, even of 
the same ethnicity or nationality, being relatively rare in the early twentieth century (Pagnini \& Morgan, 1990).

The discrimination and negative attitudes suffered by Irish immigrants were, unfortunately, not unique to that group of immigrants. For example, Chinese immigrants (McClain, 1994), as well as those from Italy (Barret \& Roediger, 1997) and the former Soviet Union (Aroian, Norris, Patsdaughter, \& Tran, 1998) all faced similar (though also groupspecific) oppression and discrimination upon immigrating to the United States. However, this discrimination toward immigrants is not a problem only found in history books. Current immigrants living in the United States continue to face discrimination in employment, labor, and education (Portes \& Rumbaut, 2006), as well as prejudice in their social interactions and disparity in healthcare and outcomes (Alegría et al., 2008; Mesch, Turheman, \& Fishman, 2008; Pérez, Fortuna, \& Alegría, 2008; Yoo, Gee, \& Takeuchi, 2009).

The negative attitudes that many U.S. citizens have toward immigrants are influenced by many variables. When immigrants are perceived as threatening, U.S. Americans tend to have more negative perceptions of the immigrants, though interpersonal contact with immigrants leads to more positive perceptions of them (Ceballos \& Yakushiko, 2014). People in the U.S., U.K., and Canada had more positive attitudes toward immigrants when the participants felt that they had control (via a strong internal locus of control) and when they felt that their society had control over immigration (Harell, Soroka, \& Iyengar, 2017). People also prefer immigrants who they preceive as highly-skilled compared to those with low or no skills - and interestingly, this preference for highly skilled immigrants is true for people whether they themselves are wealthy or poor (Hainmmeuller \& Hiscox, 2010). 
Other characteristics of immigrants also influence how they are perceived. Physical racial characteristics (Ostfeld, 2017) - with White immigrants preferred over non-White immigrants, and gender (Garg \& Seeborg, 2010) - with men perceived more positively than women, influence how U.S. Americans perceive immigrants. And, as with most such issues, the intersection of various immigrant characteristics are important to note. For example, an examination of how immigrants from the (very large and diverse) continent of Africa fared in the labor market in 1980, 1990, and 2000 found that the market (e.g., employers and consumers) preferred White male immigrants, followed by Black male immigrants, White female immigrants, and finally Black female immigrants (Borch \& Corra, 2010).

U.S. Americans pick up theses preferences early. Children in elementary school, who were presented with vignettes about fictional immigrants, were more likely to see Arab Muslim male immigrants as hostile than White Irish male immigrants. However, those children who viewed Muslim Americans as prototypical Americans (and who strongly identified as American themselves) had less negative perceptions of the Arab Muslim immigrants (Brown, Ali, Stone, \& Jewell, 2017).

One way to investigate these types of attitudes and how they might affect the interpersonal interactions between U.S. citizens and immigrants is through the theory of social distance. Since the 1920 s, social distance has been used to investigate how comfortable someone feels in the presence of members of an out-group (Wark \& Galliher, 2007). For decades, research has shown that people use characteristics such as race, social class, gender, and nationality to determine the amount of social distance they prefer from others (Parrillo \& Donoghue, 2005; Triandis \& Triandis, 1960), and that social distance is at least one of the 
variables that influences the relationship between attitudes and behavior (Warner \& DeFleur, 1969).

While the average amounts of desired social distance from members of outgroups have changed over time, social distance is still a powerful way to determine how participants think and feel about outgroup members (Parrillo \& Donoghue, 2005). The best known social distance scale was developed by Bogardus (1933), and has been adapted various times to meet current and specific situations (e.g., Byrnes \& Kiger, 1988; Parrillo \& Donaghue, 2005). The basic foundation of the scale is simple and merely asks participants to indicate how comfortable they would feel with a specific person being in their live at different levels of intimacy (e.g., personal friend, co-worker, tourist in their country). By utilizing such a measure, it is possible to determine not only how participants feel about members of a specific outgroup, but also to explore how they feel about one group relative to another.

\section{The Current Study}

In the current study, we explored participants' attitudes about immigration by asking about their preferred social distance from a specific (fictional) immigrant whom they read about in a vignette. Our interest was originally piqued because of the campaign rhetoric of 2016, and, as suggested by previous research (Garg \& Seeborg, 2010; Ostfeld, 2017), we were curious to see if people at that time distinguished among immigrants with different demographic characteristics (i.e., gender, occupation, and country of origin) and if the demographics of the participants (e.g., age, gender, level of education) were related to their immigration attitudes (Brown, Ali, Stone, \& Jewell, 2017; Hainmmeuller \& Hiscox, 2010).

We tested various hypotheses. First, we hypothesized that a fictional immigrant from England would be rated as more favorable than fictional immigrants from India or Syria (see 
Brown et al., 2017). In other words, participants would desire less social distance from the English immigrants. Second, we hypothesized that participants would desire less social distance from fictional immigrants with professional occupations (doctor, teacher) than unskilled occupations (janitor; see Hainmmeuller \& Hiscox, 2010). Third, based on previous research, we hypothesized that participants would desire less social distance from immigrants who are men than those who are women (Borch \& Corra, 2010). Finally, we hypothesized that there would be an interaction among the demographics of the fictional immigrants, with participants preferring English immigrants who were men with professional occupations over all other immigrants (see Borch \& Corra, 2010).

\section{Method}

\section{Participants}

Participants were 616 adults from across the United States recruited online from Amazon Mechanical Turk (MTurk; http://www.mturk.com). Participants ranged in age from 18 to 78, with the average age of participants being 39.88 years $(S D=12.04$ years $)$. There was about an equal split in terms of sex, with $47.2 \%$ of the sample identifying as female and $45.5 \%$ identifying as male. In terms of ethnicity, $75.6 \%$ of the participants identified as White, $7.7 \%$ as Black, $5.3 \%$ as Hispanic, and $4.1 \%$ identified as "other." The majority $(58 \%)$ of participants were employed full-time, while $15.2 \%$ were employed part-time, $15 \%$ unemployed, and only $3.6 \%$ identified as full-time students. Socioeconomic status (SES) was measured in terms of individuals' highest level of education as well as reported yearly-adjusted gross income. As a whole, the sample was relatively well-educated: $36.8 \%$ of the participants had a Bachelor's degree, $31.7 \%$ attended some college, $12.7 \%$ had a graduate degree, and $11.5 \%$ had a high school degree. The mean yearly-adjusted gross income was $\$ 39,586.17(S D=\$ 76,835.20)$. 


\section{Measures and Materials}

Vignettes. In the experiment, participants were randomly presented with one of 18 different vignettes. The vignettes varied based on three demographics of the main character in the vignette: gender (man or woman), country of origin (England, India, or Syria), and occupation (doctor, teacher, or janitor). Gender was varied based on the names used of immigrants and the pronouns in the vignette. Country of origin was stated within the vignette and names were also changed to fit the country of origin. For example, Jack and Jessica were immigrants from England, Arjun and Saanvi were immigrants from India, and Adnan and Amira were immigrants from Syria. Finally, occupation was also explicitly stated in the vignette. See Appendix A for an example of a full vignette script. The vignettes consisted of a paragraph explaining that the character was a recent immigrant to the United States and was having trouble finding a job similar to the one he or she held in his or her home country. The vignette also mentioned the immigrant's previous job. Finally, the vignette stated that the purpose of this study was an employment survey to help an organization (albeit fictitious), the Center for Job Creation, gather information to help the immigrant and similar others find work.

Social Distance. We revised an eight-item social distance scale (Byrnes \& Kiger, 1988), based on the original Bogardus (1933) social distance scale, to assess participants' comfort and desired social distance with the vignette immigrant in different roles. Each question stem was the same, "I believe I would be happy to have (name):" and there were eight different roles. A sample item was, "I believe I would be happy to have Jessica as mayor of my town" and participants responded on a seven-point scale that ranged from 1 (Very Uncomfortable) to 7 (Very Comfortable). Mean scores were computed with higher scores indicating more comfort and less desired social distance $(\alpha=.85)$. 
Demographics. Demographic information was also collected from participants. This included age, sex, ethnicity, highest level of education, religious denomination, sexual orientation, relationship information, employment status, yearly adjusted gross income, and political ideology.

\section{Procedure}

Participants were recruited online via MTurk between February 2016 and August 2016. MTurk is a crowdsourcing platform where workers/participants can choose to complete tasks or surveys for small compensation. In this instance, participants were compensated $\$ 1.00$ for their time. Consent was obtained prior to participation on the first page of the online survey. After consenting, participants were randomly presented with one of the 18 different vignettes about an immigrant. The vignettes varied based on country of origin (England, India, or Syria), gender (male or female), and occupation (doctor, teacher, or janitor). After reading the vignette, participants filled out the social distance measure based on the immigrant they had read about. After completing the social distance measure, participants provided demographic information.

\section{Results}

Tables 1 and 2 contain descriptive information (e.g. $M \mathrm{~s}, S D$ s, frequencies) for the study variables. Preliminary bivariate correlations were conducted between all participant demographic variables (i.e. age, gender, ethnicity, education level, income, and employment) and the outcome variable of social distance. Lower scores on social distance indicated greater desired social distance. Results from the bivariate correlations suggested that only age significantly correlated with social distance $(r=-.08, p<.05)$, with older participants reporting generally higher levels of desired social distance across all immigrant groups (See Table 3). 


\section{Table 1}

Frequency and Mean Characteristics of Study Variables

\begin{tabular}{|c|c|c|c|c|}
\hline Characteristic & $M$ & $S D$ & $n$ & $\%$ \\
\hline Social Distance & 3.90 & 1.34 & & \\
\hline Age & 39.88 & 12.04 & & \\
\hline Adjusted Gross Income (2015) & $39,586.17$ & $76,835.30$ & & \\
\hline \multicolumn{5}{|l|}{ Sex } \\
\hline Female & & & 323 & 47.2 \\
\hline Male & & & 312 & 45.5 \\
\hline \multicolumn{5}{|l|}{ Ethnicity } \\
\hline African-American & & & 53 & 7.7 \\
\hline Hispanic & & & 36 & 5.3 \\
\hline Other & & & 28 & 4.1 \\
\hline White & & & 518 & 75.6 \\
\hline \multicolumn{5}{|l|}{ Highest Level of Education } \\
\hline High School & & & 79 & 11.5 \\
\hline Some College & & & 217 & 31.7 \\
\hline Bachelor's Degree & & & 252 & 36.8 \\
\hline Graduate Degree & & & 87 & 92.7 \\
\hline \multicolumn{5}{|l|}{ Employment Status } \\
\hline Full-Time Employed & & & 404 & 59.0 \\
\hline Part-Time Employed & & & 118 & 17.2 \\
\hline Student & & & 27 & 3.9 \\
\hline Unemployed & & & 103 & 15.0 \\
\hline
\end{tabular}

Note. Participants could select more than one employment status category if applicable. 
Table 2

Demographics by Vignette

\begin{tabular}{|c|c|c|c|c|c|c|}
\hline \multirow[b]{2}{*}{ Vignette } & \multicolumn{2}{|c|}{ Age } & \multicolumn{2}{|c|}{ Sex } & \multicolumn{2}{|c|}{ Social Distance } \\
\hline & $M$ & $S D$ & $\%$ Male & $\%$ Female & $M$ & $S D$ \\
\hline $\begin{array}{l}\text { 1. English, Male } \\
\text { Doctor }(n=38)\end{array}$ & 39.37 & 12.47 & 41.5 & 53.7 & 4.52 & 1.14 \\
\hline $\begin{array}{l}\text { 2. English, Male } \\
\text { Teacher }(n=34)\end{array}$ & 40.39 & 10.26 & 48.6 & 43.2 & 4.63 & 1.04 \\
\hline $\begin{array}{l}\text { 3. English, Male } \\
\text { Janitor }(n=38)\end{array}$ & 40.66 & 13.60 & 38.5 & 59.0 & 4.14 & 1.49 \\
\hline $\begin{array}{l}\text { 4. English, Female } \\
\text { Doctor }(n=34)\end{array}$ & 42.59 & 10.92 & 52.9 & 47.1 & 4.47 & 1.07 \\
\hline $\begin{array}{l}\text { 5. English, Female } \\
\text { Teacher }(n=36)\end{array}$ & 39.94 & 13.03 & 55.6 & 44.4 & 4.77 & 1.11 \\
\hline $\begin{array}{l}\text { 6. English, Female } \\
\text { Janitor }(n=34)\end{array}$ & 40.50 & 12.94 & 64.7 & 35.3 & 4.10 & 1.33 \\
\hline $\begin{array}{l}\text { 7. Indian, Male } \\
\text { Doctor }(n=34)\end{array}$ & 38.35 & 11.39 & 41.7 & 52.8 & 3.63 & 1.21 \\
\hline $\begin{array}{l}\text { 8. Indian, Male } \\
\text { Teacher }(n=35)\end{array}$ & 37.71 & 11.78 & 56.8 & 37.8 & 3.65 & 1.05 \\
\hline $\begin{array}{l}\text { 9. Indian, Male } \\
\text { Janitor }(n=36)\end{array}$ & 40.69 & 13.73 & 36.4 & 60.5 & 3.68 & 1.17 \\
\hline $\begin{array}{l}\text { 10. Indian, Female } \\
\text { Doctor }(n=36)\end{array}$ & 40.78 & 12.25 & 36.1 & 63.9 & 4.16 & 1.27 \\
\hline $\begin{array}{l}\text { 11. Indian, Female } \\
\text { Teacher }(n=36)\end{array}$ & 38.17 & 9.11 & 47.2 & 52.8 & 3.87 & 1.26 \\
\hline $\begin{array}{l}\text { 12. Indian, Female } \\
\text { Janitor }(n=38)\end{array}$ & 41.16 & 11.78 & 59.0 & 41.0 & 3.88 & 1.16 \\
\hline $\begin{array}{l}\text { 13. Syrian, Male } \\
\text { Doctor }(n=31)\end{array}$ & 38.48 & 10.09 & 54.8 & 45.2 & 3.62 & 1.44 \\
\hline $\begin{array}{l}\text { 14. Syrian, Male } \\
\text { Teacher }(n=35)\end{array}$ & 38.43 & 10.40 & 48.6 & 51.4 & 3.54 & 1.64 \\
\hline $\begin{array}{l}\text { 15. Syrian, Male } \\
\text { Janitor }(n=30)\end{array}$ & 41.07 & 12.94 & 37.8 & 43.2 & 2.79 & 1.05 \\
\hline $\begin{array}{l}\text { 16. Syrian, Female } \\
\text { Doctor }(n=48)\end{array}$ & 43.50 & 13.96 & 47.4 & 52.6 & 3.74 & 1.27 \\
\hline $\begin{array}{l}\text { 17. Syrian, Female } \\
\text { Teacher }(n=36)\end{array}$ & 37.83 & 11.49 & 47.2 & 52.8 & 3.79 & 1.53 \\
\hline $\begin{array}{l}\text { 18. Syrian, Female } \\
\text { Janitor }(n=34)\end{array}$ & 37.88 & 13.52 & 50.0 & 50.0 & 3.80 & 1.42 \\
\hline
\end{tabular}

Note. For all measures, higher scores on social distance indicate more comfort and less desired social distance. 


\section{Table 3}

Bivariate Correlations Between Demographic Variables and Social Distance

\begin{tabular}{|c|c|c|c|c|c|c|c|}
\hline Measure & 1 & 2 & 3 & 4 & 5 & 6 & 7 \\
\hline 1. Social Distance & - & & & & & & \\
\hline 2. Age & $-.08 *$ & - & & & & & \\
\hline 3. Gender & .04 & $.28 * * *$ & - & & & & \\
\hline 4. Ethnicity & .03 & $-.13 * *$ & $.08 *$ & - & & & \\
\hline 5. Education Level & -.04 & .02 & -.06 & .05 & - & & \\
\hline 6. Income & .00 & -.06 & $-.14 * * *$ & -.02 & $.23 * * *$ & - & \\
\hline 7. Employment Status & .01 & $.14 * *$ & $.15^{* * *}$ & .06 & $-.13 * *$ & $-.20 * * *$ & - \\
\hline
\end{tabular}

Note. $* p<.05 . * * p<.01 . * * * p<.001$.

Additionally, exploratory group difference tests were conducted to determine if there were mean level differences in desired social distance from the immigrant in each vignette as a function of participants' categorical demographic variables (i.e. gender, ethnicity, education level, and employment). Specifically, there were no mean group differences on social distance between gender, $t(1,635)=-1.09, p=.28$, ethnicity, $F(3,634)=0.35, p=.80$, education level, $F(3,634)=1.56, p=.20$, and employment level groups, $F(3,628)=0.23, p=.89$. Therefore, the only covariate included in the analysis was age.

A 3 (country) x 2 (gender) x 3 (occupation) between subjects analysis of covariance (ANCOVA) was conducted to see if differences in desired social distance from the immigrant presented in the vignette were a function of the immigrant's country of origin (England, India, or Syria), gender (man or woman), and occupation (doctor, teacher, or janitor) while controlling for 
the age of the participants. Follow-up pairwise $t$ tests with a Bonferonni correction were employed to decipher differences between country of origin and occupation.

In line with our hypothesis, there was a significant, small-to-medium main effect of country, $F(2,633)=29.22, p<.001, \eta^{2}=.09$. Bonferonni post hoc comparisons indicated that participants desired more social distance from both Indian immigrants $(M=3.77, S D=1.19, p<$ $.001)$ and Syrian immigrants $(M=3.54, S D=1.43, p<.001)$ than from English immigrants $(M=$ $4.45, S D=1.22)$. There was no difference in desired social distance between Indian and Syrian immigrants.

The ANCOVA also yielded a significant but small main effect of gender, $F(1,633)=$ $5.89, p=.02, \eta^{2}=.01$, such that participants wanted more social distance from immigrants who were men $(M=3.80, S D=1.35)$ than those who were women $(M=4.04, S D=1.31)$. Finally, there was a significant but small main effect of occupation, $F(2,633)=4.90, p=.01, \eta^{2}=.02$. Follow up Bonferonni post hoc comparisons indicated that participants desired more social distance from immigrants who were janitors $(M=3.70, S D=1.34)$ than immigrants who were doctors $(M=4.03, S D=1.28, p=.02)$ and immigrants who were teachers $(M=4.03, S D=1.37$, $p=.02)$. There was no difference between the desired social distance from teachers and doctors.

Contrary to our hypotheses, there were no significant two-way or three-way interactions between the immigrant's country, gender, and occupation, and social distance. See Table 4 for full results from the ANCOVA. 


\section{Table 4}

Summary Table for Analysis of Covariance of the Effects of Country of Origin, Gender and Occupation on Social Distance while controlling for Age

\begin{tabular}{lcccccc}
\hline \multicolumn{1}{c}{ Variable } & $d f$ & $S S$ & $M S$ & $F$ & $p$ & Partial $\eta^{2}$ \\
\hline Age (Covariate) & 1 & 8.68 & 8.68 & 5.40 & .02 & .01 \\
Country & 2 & 93.83 & 46.91 & 29.22 & $<.001$ & .09 \\
Gender & 1 & 9.44 & 9.44 & 5.89 & .02 & .01 \\
Occupation & 2 & 15.74 & 7.87 & 4.90 & .01 & .02 \\
Country x Gender & 2 & 4.92 & 2.46 & 1.53 & .22 & .01 \\
Gender x Occupation & 2 & 0.29 & 0.15 & 0.09 & .91 & .00 \\
Country x Occupation & 4 & 4.82 & 1.21 & 0.75 & .56 & .00 \\
Country x Gender x Occupation & 4 & 10.18 & 2.54 & 1.59 & .18 & .01 \\
\hline
\end{tabular}

Note. $\mathrm{SS}=$ sum of squares; $\mathrm{MS}=$ mean square

\section{Discussion}

We found that U.S. Americans have a preference for immigrants (and, we believe, refugees) who are women, from England, or have professional careers compared to those that are men, from India or Syria, or have a non-professional career. Most of our findings support and extend previous research on this topic, but we were surprised that there was not an interaction among the different characteristics of the immigrants in the vignettes presented to participants.

Physical racial characteristics of immigrants influence the way that they are perceived by U.S. Americans (Ostfeld, 2017). We assume that this is, at least partially, the reason that participants in this study preferred immigrants from England over those from India and Syria. While we did not mention anything about race or ethnicity in the vignette participants read, it is 
reasonable to assume that they had a mental image of a stereotypical person from each of these countries - and that that image would be of a White person from England, and darker complexed people from Syria and India. Future research on this topic might consider alternating the race and/or ethnicity of the fictional immigrant presented to participants to determine how much this characteristic influences participants' perceptions beyond the influence of nationality.

Our finding that participants desired less social distance from immigrants who have professional careers (in our study, doctors or teachers) compared to those with non-professional careers (janitors) fits well with previous research. For example, Hainmuller and Hiscox (2010) found a preference for highly-skilled immigrants in relation to immigrants with low or no professional skills. Much of the research that has examined how the careers and skills of immigrants influence how they are perceived has been conducted through a lense of economics and labor markets. Even the current study was presented to participants as a study about a fictional Center for Job Creation. It would be interesting for future researchers to develop a creative and implicit way to examine the role of skills and career in the perception of immigrants without explicitly connecting data collection to economics or labor.

Two of our hypotheses were not supported. We expected, based on previous research (e.g., Borch \& Corra, 2010; Garg \& Seeborg, 2010), to find that men immigrants would be preferred to women immigrants. We found the opposite, however; our participants preferred women immigrants over men immigrants. While this does not fit well with previous research, we wonder if it might be an effect of current political commentary about immigrants and refugees being violent and dangerous. If participants perceive men immigrants as more threatening than women immigrants, this might explain the preference for women immigrants - 
especially as previous research has found that U.S. Americans who see immigrants as a threat are likely to have a more negative perception of them (Ceballos \& Yakushiko, 2014).

We also expected to find an interaction effect, where the immigrant's gender, nationality, and career would all interact in the way they were perceived by our participants. This was not the case, though. Our participants preferred women immigrants, immigrants from England, and immigrants with professional careers independently of the immigrant's other characteristics. While our means indicated that participants desired the most distance from Syrian male janitors $(M=2.79, S D=1.05)$ and the least from English female teachers $(M=4.77, S D=1.11)$, these differences were not found to interact signficiantly across immigrant group characteristics as indicated by the ANCOVA. Previous research has found that immigrants' characteristics do interact in the way they are perceived - such as an immigrant's gender and race, for example (Borch \& Corra, 2010). It is possible that we did not find an interaction effect because of the characteristics we provided about the immigrants in the vignette - perhaps gender and race do interact, but gender and nationality do not. Future research should explore this possibility.

There are various strengths to this study. For example, we were able to replicate a methodology among our adult participants that has been successful with children (Brown et al., 2017). The current study also addresses a pressing and important current issue. Understanding how people in the United States think about immigrants based upon the characteristics of the immigrants is as important now as it ever has been.

In addition to these strengths, there are also some limitations to our study. As discussed previously, our results might be specific to the characteristics we provided about the immigrants in our vignettes. Different countries of origin and occupations might lead to different results. This includes characteristics that we did not study (such as race, ethnicity, religion, or age) that 
might also influence the way participants perceive the immigrants. We also did not screen our participants to determine their own immigration status; so while all participants were residing in the United States when they participated in the study, we cannot be certain that all of them were U.S. citizens or legal residents. We also think that future projects on this topic should include a measure of social desirability and various measures of social distance (or additional measures of participants' perceptions about the immigrants in the vignettes). It might also be interesting to add measures of individual differences about the participants, such as social dominance orientation, political ideology, or authoritarianism.

Even with the limitations mentioned, this study provides important information about how people in the United States perceive immigrants by measuring the social distance participants desire from fictional immigrants. This study shows us that attitudes toward immigrants are not objective or static, and that immigrants are judged based upon factors such as gender, national origin, and occupation. The concern we should have is not whether these personal atittudes influence policy and law, but how these personal attitudes influence immigration policy and law.

While our data was collected in the months leading up to the 2016 U.S. presidential election, much has occurred in the time since the election that reflects personal and political attitudes about immigration (such as multiple versions of a travel ban on people from certain nations and the testing of prototypes of a wall to be built along the U.S.-Mexican border). It is vital that we continue to explore and attempt to understand the psychology behind how prejudicial and unequal attitudes about immigration are influencing policy and, hence, impacting the lives of immigrants and refugees (Berry, 2001). 


\section{References}

Alegría, M., Canino, G., Shrout, P. E., Woo, M., Duan, N., Villa, D., Torres, M., Chen, C-n., \& Meng, X-L. (2008). Prevalence of mental illness in immigrant and non-immigrant U.S. Latino groups. The American Journal of Psychiatry, 165, 359-369. doi:10.1176/appi.ajp.2007.07040704

Aroian, K. J., Norris, A. E., Patsdaughter, C. A., \& Tran, T. V. (1998). Predicting psychological distress among former Soviet immigrants. International Journal of Social Psychiatry, 44, 284-294. doi:10.1177/002076409804400405

Barret, J. R. \& Roediger, D. (1997). Inbetween peoples: Race, nationality and the new immigrant working class. In R. Halpern \& J. Morris (Eds.), American Exceptionalism? (181-220). London, UK: Palgrave Macmillan.

BBC (2017, September). Trump's promises before and after the election. British Broadcasting Company. Retrieved from http://www.bbc.com/news/world-us-canada-37982000

Berry, J. W. (2001). A psychology of immigration. Journal of Social Issues, 57, 615-631. doi: $10.1111 / 0022-4537.00231$

Blau, F. D. (1980). Immigration and labor earnings in early twentieth century America. In J. L. Simon \& J. Da Vanzo (Eds.), Research population economics: A research annual (2144). Greenwich, CT: JAI Press.

Bogardus, E. S. (1933). A social distance scale. Sociology \& Social Research, 17, 265-271.

Borch, C., \& Corra, M. K. (2010). Differences in earnings among black and white African immigrants in the United States, 1980-2000: A cross-sectional and temporal analysis. Sociological Perspectives, 53, 573-592. doi:10.1525/sop.2010.53.4.573

Brown, C. S., Ali, H., Stone, E. A., \& Jewell, J. A. (2017). U.S. children's stereotypes and 
prejudicial attitudes toward Arab Muslims. Analyses of Social Issues and Public Policy. Advance online publication. doi:10.1111/asap.12129

Byrnes, D. A. \& Kiger, G. (1988). Contemporary measures of attitudes toward Blacks. Education and Psychological Measurement, 48, 107-118. doi:10.1177/001316448804800113

Ceballos, M., \& Yakushko, O. (2014). Attitudes toward Immigrants in Nebraska. Great Plains Research, 24, 181-195. doi: 10.1353/gpr.2014.0042

Connor, P. (2017, October). After record migration, 80\% of Syrian asylum applicants approved to stay in Europe. Retrieved from http://www.pewresearch.org/facttank/2017/10/02/after-record-migration-80-of-syrian-asylum-applicants-approved-tostay-in-europe/

Daniels, R. (2002). Coming to America: A history of immigration and ethnicity in American life. New York City, NY: Harper Perennial

Hainmueller, J., \& Hiscox, M. J. (2010). Attitudes toward highly skilled and low-skilled immigration: Evidence from a survey experiment. American Political Science Review, 104, 61-84. doi: 10.1017/S0003055409990372

Harell, A., Soroka, S., \& Iyengar, S. (2017). Locus of control and anti-immigrant sentiment in Canada, the United States, and the United Kingdom. Political Psychology, 38, 245-260. doi:10.1111/pops.12338

Immigration and Naturalization Service (2012). Overview of INS history. Washington, D.C.: U.S. Citizenship and Immigration Services History Office and Library.

Garg, M., \& Seeborg, M. C. (2010). The effect of place of origin on the relative earnings of 
immigrant women. International Business \& Economics Research Journal, 9, 117-128. doi:10.19030/iber.v9i2.528

McClain, C. J. (1994). In search of equality: The Chinese struggle against discrimination in nineteenth-century America. Berkely, CA: University of California Press.

Mesch, G. S., Turjeman, H., \& Fishman, G. (2008). Perceived discrimination and the well-being of immigrant adolescents. Journal of Youth and Adolescence, 37, 592-604. doi:10.1007?s10964-007-9210-6

Miller, K. A. (1985). Emigrants and exiles: Ireland and the Irish exodus to North America. New York City, NY: Oxford University Press.

Ostfeld, M. (2017). The backyard politics of attitudes toward immigration. Political Psychology, 38, 21-37. doi: 10.1111/pops.12314

Pagnini, D. L. \& Morgan, S. P. (1990). Intermarriage and social distance among U.S. immigrants at the turn of the century. American Journal of Sociology, 96, 405-432. doi:10.1086/229534

Parrillo, V. N. \& Donoghue, C. (2005). Updating the Bogardus social distance studies: A new national survey. The Social Science Journal, 42, 257-271. doi:10.1016/j.soscij.2005.03.011

Pérez, D. J., Fortuna, L., \& Alegría, M. (2008). Prevalence and correlates of everyday discrimination among U.S. Latinos. Journal of Community Psychology, 36, 421-433. doi:10.1002/jcop.20221

Portes, A. \& Rumbaut, R. G. (2006). Immigrant America: A portrait. Berkely, CA: University of California Press.

Time (2015, July). Here's Donald Trump's presidential announcement speech. Time. Retrieved 
from http://time.com/3923128/donald-trump-announcement-speech/

Triandis, H. C., \& Triandis, L. M. (1960). Race, social class, religion, and nationality as determinants of social distance. The Journal of Abnormal and Social Psychology, 61, 110-118. doi:10.1037/h0041734

Wark, C. \& Galliher, J. F. (2007). Emory Bogardus and the origin of the social distance scale. The American Sociologist, 38, 383-395. doi: 10.1007/s12108-007-9023-9

Warner, L. G. \& DeFleur, M. L. (1969). Attitude as an interactional concept: Social constraint and social distance as intervening variables between attitudes and action. American Sociological Review, 34, 153-160. doi: 10.2307/2092174

Yoo, H. C., Gee, G. C., \& Takeuchi, D. (2009). Discrimination and health among Asian American immigrants: Disentangling racial from language discrimination. Social Science \& Medicine, 68, 726-732. doi:10.1016?j.socscimed.2008.11.013 


\section{Appendix A}

\section{Example Vignette for Indian Immigrant}

Arjun/Saanvi is a recent immigrant to the United States from India. He/She has been in the U.S.

for 15 months, and has had trouble finding a job similar to the one he/she had in India. Before immigrating, he/she was a doctor/teacher/janitor. As part of an employment study, the Center for Job Creation is gathering information to help Arjun/Saanvi and people like him/her find work. 